\title{
Variation of larval size and adult emergence period of Boyeria irene (Fonscolombe, 1838) (Odonata: Aeshnidae) in the Francia River of western Spain
}

Patricia Casanueva, M. Ángeles Hernández, Luisa Nunes, Luis Fernando Sánchez-Sastre \& Francisco Campos

To cite this article: Patricia Casanueva, M. Ángeles Hernández, Luisa Nunes, Luis Fernando Sánchez-Sastre \& Francisco Campos (2021): Variation of larval size and adult emergence period of Boyeria irene (Fonscolombe, 1838) (Odonata: Aeshnidae) in the Francia River of western Spain, Aquatic Insects, DOI: 10.1080/01650424.2021.1959037

To link to this article: https://doi.org/10.1080/01650424.2021.1959037

\section{冊 Published online: 22 Dec 2021.}

\section{Submit your article to this journal $\square$}

Щ Article views: 18

Q View related articles $\asymp$

View Crossmark data 


\title{
Variation of larval size and adult emergence period of Boyeria irene (Fonscolombe, 1838) (Odonata: Aeshnidae) in the Francia River of western Spain
}

\author{
Patricia Casanueva ${ }^{a}$, M. Ángeles Hernández ${ }^{b}$, Luisa Nunes ${ }^{c, d}$, \\ Luis Fernando Sánchez-Sastre ${ }^{\mathrm{e}}$ and Francisco Campos $^{\mathrm{a}}$ \\ ${ }^{a}$ Universidad Europea Miguel de Cervantes, Valladolid, Spain; ${ }^{\mathrm{b}}$ Facultad de Ciencias, Universidad de \\ Navarra, Pamplona, Spain; 'Escola Superior Agrária de Castelo Branco, Castelo Branco, Portugal; \\ ${ }^{\mathrm{d}}$ Centre for Applied Ecology Prof. Baeta Neves (CEABN-InBIO), School of Agriculture, University of \\ Lisbon, Lisbon, Portugal; ' Escuela Técnica Superior de Ingenierías Agrarias, Universidad de Valladolid, \\ Palencia, Spain
}

\begin{abstract}
Boyeria irene (Fonscolombe, 1838) is a large dragonfly common in rivers and streams in southern Europe, but it is little known about the biometrical variations of their populations. In this paper, we test whether the time of the emergence period of this species differs in the same river, whether the larval size varies during the emergence period, and whether the distinct size variations are associated with the different river sections. Results have revealed that 1) female exuviae are larger than those of males, 2) except for the paraproct length, the exuviae have similar size across the entire river length, 3) size of the exuviae is larger in the first period of emergence than in the second one. A difference in emergence duration across the three river sections has been recorded.
\end{abstract}

\section{ARTICLE HISTORY}

Received 5 March 2021

Revised 15 July 2021

Accepted 16 July 2021

\section{KEYWORDS}

Dragonflies; exuviae; Iberian Peninsula; odonates; river

\section{Introduction}

Biometric comparisons allow us to know whether a species varies in size over wide geographic areas, as has been shown for various insect species (e.g., Hassall, Keat, Thompson, and Watts 2014; Horne, Hirst, and Atkinson 2015; Zeuss, Brunzel, and Brandl 2017; Casanueva et al. 2020). Several hypotheses have been proposed to explain variation in their body size; among them the temperature-size rule, TSR (Atkinson 1994), which proposes that the development rate increases with temperature, thus the body size of adult specimens may be smaller in warmer areas, as well as later in season. This rule has been applied to both uni- and multicellular organisms (Atkinson, Morley, and Hughes 2006).

Odonates have an aquatic phase of variable duration in their life cycle, during which successive moults occur allowing the larva to grow until it reaches the final stage (Corbet 2004). A preliminary step towards biometric comparisons of populations is to 
check whether specimens in the same population have the similar size within the same developmental instar. It has been shown that the size of adults varies between first emerging and later emerging, both in damselflies (Plaistow and Siva-Jothy 1999) and dragonflies (Minot, Le Gall, and Huste 2019), but not in all species (Wonglersak, Fenberg, Langdon, Brooks, and Price 2020).

The onset and duration of the adult emergence period vary with geographic location and environmental conditions, especially they depend on water temperature: the higher the temperature, the earlier adult emerge (Corbet 2004; Hassall and Thompson 2008; Farkas, Jakab, Tóth, Kalmár, and Dévai 2012). The northern half of the Iberian Peninsula (approximately $40^{\circ}-43^{\circ} \mathrm{N}$ ) has a colder climate than the southern half (approximately $36^{\circ}-40^{\circ} \mathrm{N}$ ) (Ninyerola, Pons, and Roure 2005). It seems logical to assume that for the water temperature in the rivers of the northern half, it takes more time to reach the minimum level to trigger the metamorphosis of aquatic larvae. Therefore, there might be a considerable time lag in the onset of the emergence period between the northern and southern halves (Casanueva, Hernández, Campos, and Santamaría 2017). This should also be taken into account when analysing the biometry of populations of the same species over large geographical areas. However, it is legitimate to ask whether the same divergence occurs at a local scale when environmental conditions vary between nearby sites. Mountain rivers are a suitable setting to analyse the response of organisms to changes in environmental conditions, as they flow through areas where these conditions change significantly.

Boyeria irene (Fonscolombe, 1838) (Odonata: Aeshnidae) is a large species $(3-4 \mathrm{~cm}$ of total length of larvae in the final stage, designated as F-0) living mainly in southern Europe (Boudot et al. 2009). In the Iberian Peninsula, it behaves as a partivoltine in the centre (Velasco, Norling, Campos, and Ferreras-Romero 2018) and bivoltine in the south (Ferreras-Romero 1997), with a pattern of emergence suitable for a summer species (sensu Corbet, 1954, 1964). A biometric analysis of exuviae has been performed by Nunes, Casanueva, Santamaría, Hernández, and Campos (2021) and Ferreras-Romero and Suhling (2021) have analysed the morphological variation of females in a population located in southern Spain.

In this paper, we present data on the adult emergence of $B$. irene in order to test whether, in the same river (Francia River, western Spain), its emergence period differs between zones and whether larval size varies during the emergence period and between zones.

\section{Material and methods}

\section{Study area}

The Francia River is located in the hydrographic basin of the Tagus River, in westcentral Spain. Its length is $25 \mathrm{~km}$, with a steep gradient, as it rises at $1320 \mathrm{~m}$ above sea level (a.s.l.) and flows into the Alagón River at $405 \mathrm{~m}$ a.s.l. In the period of 1972-2017, its historical average flow was $76 \mathrm{hm}^{3}$ per year, with a maximum in December $\left(11.9 \mathrm{hm}^{3}\right)$ and minimum in August $\left(0.5 \mathrm{hm}^{3}\right.$ ) (data available at www. chtajo.es), measured at the Miranda gauging station, the only one on this river. The 
Table 1. Characteristics of the three sampling sites in the Francia River.

\begin{tabular}{lccc}
\hline & Casas & Miranda & Sotoserrano \\
\hline Coordinates & $40^{\circ} 30^{\prime} \mathrm{N} 06^{\circ} 25^{\prime} \mathrm{W}$ & $40^{\circ} 29^{\prime} \mathrm{N} 06^{\circ} 00^{\prime} \mathrm{W}$ & $40^{\circ} 25^{\prime} \mathrm{N} 06^{\circ} 00^{\prime} \mathrm{W}$ \\
Altitude (m, a.s.l.) & 595 & 545 & 405 \\
Length of sampled stretch $(\mathrm{m})$ & 130 & 120 & 150 \\
Tm $\left({ }^{\circ} \mathrm{C}\right)$ & 14.0 & 14.7 & 15.1 \\
Annual precipitation $(\mathrm{mm})$ & 1124 & 946 & 971 \\
Slope $\left(\mathrm{m} \mathrm{km}^{-1}\right)$ & 32.0 & 16.4 & 3.8 \\
\hline
\end{tabular}

Tm: annual mean temperature. Tm and precipitation from Ninyerola et al. (2005).

area has a Mediterranean climate with a warm, dry summer, according to Köppen and Geiger (1936).

In the study area, the Francia River flows through a large oak forest (Quercus pyrenaica Willdenow), with the banks formed by large rocks, and through a gallery forest of alder (Alnus glutinosa (L.) Gaertner) accompanied by ferns. At the mouth of the river, the banks have poplar trees (Populus nigra Linnaeus), willows, alders and species of the genera Carex Linnaeus and Typha Linnaeus. Other odonate species present in the river sections analysed were Calopteryx virgo (Linnaeus, 1758), C. xanthostoma (Charpentier, 1825), Pyrrhosoma nymphula (Sulzer, 1776), Aeshna cyanea (Müller, 1764), Cordulegaster boltonii (Donovan, 1807) and Onychogomphus uncatus (Charpentier, 1840), all of which are typical for mountain rivers in central Spain (Santamaría, Casanueva, Nunes, and Campos 2019).

\section{Sampling}

The exuviae were collected at three sections along this river, named Casas, Miranda and Sotoserrano, whose characteristics are summarised in Table 1. The slope of each section was calculated on a 1:2500 scale map at www.ign.es/iberpix2/visor. The collection of exuviae was done weekly, carefully inspecting the substrates (ground, emergent vegetation, stones, tree trunks, logs, etc.) located in the river banks, always between 06:00 h and 11:00 h GMT. They started to be found on 15 May 2020 and ended on 19 August 2020, once no new exuviae appeared. The first week was from 15-21 May, the second week from 22-29 May, the third week from 30 May-6 June, and so forth. On each sampling day, the same section of river was sampled. The emergence phase was divided into two periods: P1 (0-50\% of emerged adults) and P2 (51-100\% of emerged adults).

The following variables were measured in each exuvia according to the criteria of Wenger (1959): paraproct length (PA), epiproct length (EP) and prementum length (PR). They are all expressed in $\mathrm{mm}$ and were obtained by the same person (FC) with a stereomicroscope equipped with a millimetre eyepiece. These three variables were chosen because in $B$. irene, they are the most suitable for intraspecies biometric analysis (Nunes et al. 2021). The sex of each exuvia was determined by the presence (females) or absence (males) of gonapophyses. Damaged exuviae, lacking the abdomen, were not sexed.

For each biometric variable, normality tests (Shapiro-Wilk) and homogeneity (Barlett's) tests were performed. When these conditions were fulfilled, variables were compared between sexes and among rivers through ANOVA, and when they were 
not, they were compared using the Kruskal-Wallis test. These calculations were done using STATA 12.1 software.

\section{Results}

A total of 410 exuviae were collected, and the sex could be determined in 405 of them, distributed as follows: 127 in Casas (69 males, 58 females), 236 in Miranda $(113,123)$ and 42 in Sotoserrano $(21,21)$. There were no significant differences in sex proportions between the three sites $\left(\chi_{1}^{2}=0.6853, \mathrm{p}=0.7099\right)$.

In all three sampling sections, adult emergence started in week 4 (June 22-28, Figure 1), but its duration varied: it ended in week 13 (August 6-12) for the two points located at higher altitudes (Casas and Miranda) and in week 10 (July 16-22) in Sotoserrano. Therefore, the duration of the emergency period was seven weeks in the final section of the river and ten weeks in the others.

The ratio (no. of exuviae collected/length of the distance travelled) was 0.977 in Casas, 1.967 in Miranda and 0.280 in Sotoserrano, i.e., at the three points sampled, $B$. irene was more abundant in Miranda, with twice as many exuviae as in Casas and seven times more than in Sotoserrano.

The adult emergence curve is sigmoidal in the three river sections (Figure 1), but $50 \%$ of adults emerged in weeks 5-6 for Sotoserrano, in weeks 8-9 for Miranda and in weeks 9-10 for Casas. The number of male and female adults emerged in periods 1 and 2 considered in this paper was statistically similar in Casas (23 males, 23 females in the first period, 46 males, 35 females in the second period; $\chi^{2}{ }_{1}=0.305$, $\mathrm{p}=0.580)$, in Miranda $\left(37,48\right.$ and 76,$\left.73 ; \chi_{1}^{2}=0.930, \mathrm{p}=0.334\right)$ and in Sotoserrano $\left(5,6\right.$ and 16,$\left.15 ; \chi^{2}{ }_{1}=0.000, \mathrm{p}=1.000\right)$.

Paraproct length, epiproct length and prementum length were larger for the male exuviae collected in the first period than in those collected in the second period, except epiproct length in Sotoserrano (Table 2), with significant differences in Casas and Miranda, but not in Sotoserrano (Table 3). Also, these three variables were larger for the female exuviae collected in the first period than in those collected in the second period (Table 2); and in this case, there was statistical significance at all three sampling points, except paraproct length at Casas (Table 3).

Within each period, the values of the variables did not vary significantly between sampling points, with the exception of PA in females (Table 4): PA was higher in Miranda $(4.08 \pm 0.20, \mathrm{n}=49)$ than in Casas $(3.95 \pm 0.16, \mathrm{n}=23)$ and Sotoserrano $(4.00 \pm 0.17, \mathrm{n}=6)$. Therefore, except for PA, for each period, the exuviae were of similar size along the entire length of the river channel.

\section{Discussion}

In Anisoptera, large samples of exuviae have shown a slight but consistent pattern of preponderance of females (Cordero-Rivera and Stoks 2008). At the three sampling points in this study, the proportion of female exuviae was greater than that of male exuviae only in the largest sample, but the differences were not statistically significant. These results are consistent with those found in other rivers of the Iberian Central 

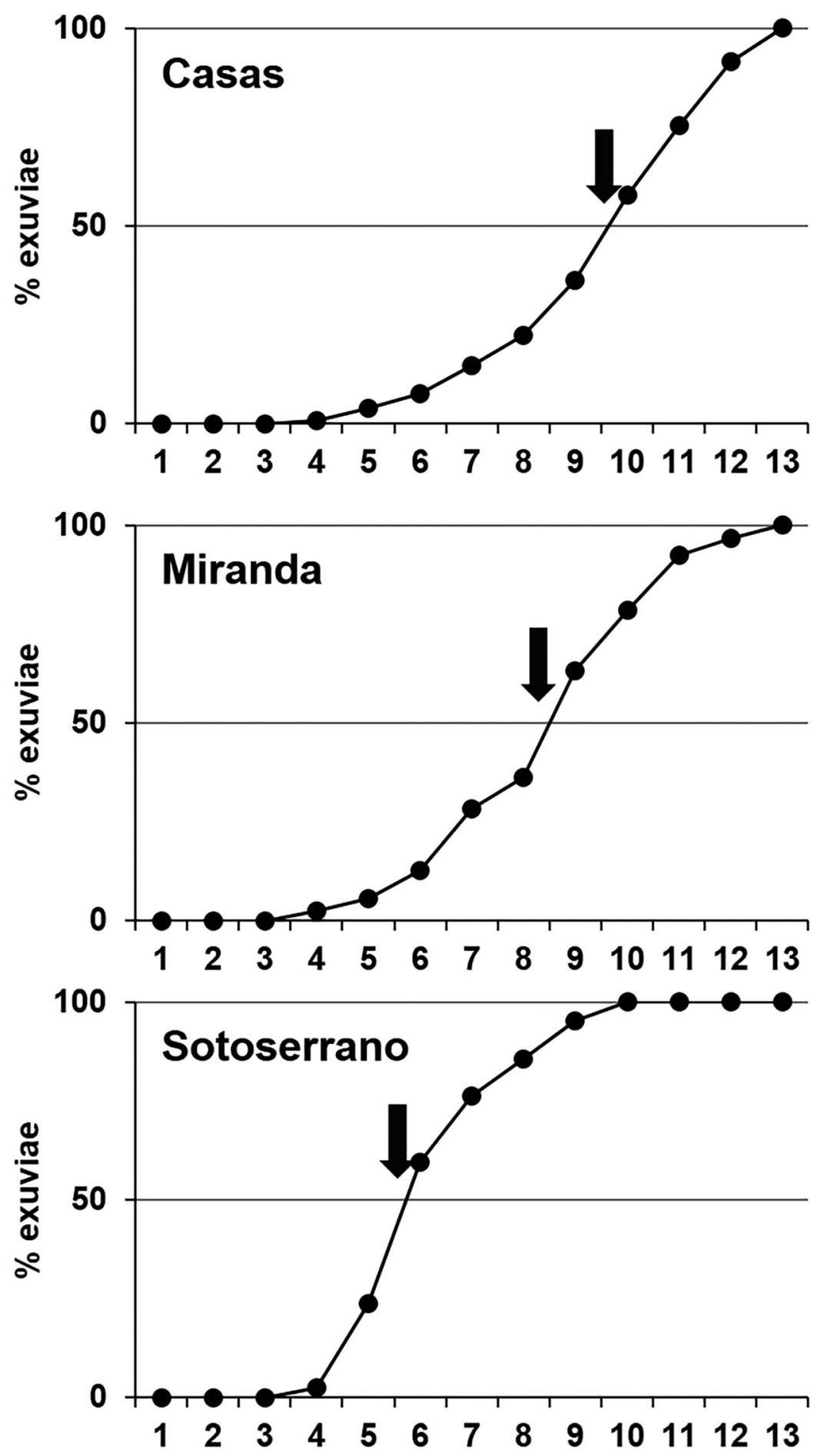

Figure 1. Cumulative number of Boyeria irene (Fonscolombe, 1838) exuviae collected over 14 weeks in the three sampling sections (Casas, Miranda, Sotoserrano) on the Francia River. Arrow indicates the week in which $50 \%$ of adults had emerged. 
Table 2. Mean value ( $\pm \mathrm{SD}$ ) of paraproct length (PA), epiproct length (EP) and prementum length $(\mathrm{PR})$ in exuviae of Boyeria irene (Fonscolombe, 1838) sampled in three sections (Casas, Miranda, Sotoserrano) from the Francia River during the first (P1) and second (P2) period (see text).

\begin{tabular}{|c|c|c|c|c|c|c|c|}
\hline & & \multicolumn{2}{|c|}{ Casas } & \multicolumn{2}{|c|}{ Miranda } & \multicolumn{2}{|c|}{ Sotoserrano } \\
\hline & & P1 & P2 & P1 & P2 & P1 & P2 \\
\hline \multirow[t]{2}{*}{ PA } & Male & $\begin{array}{c}3.88 \pm 0.16 \\
(23)\end{array}$ & $\begin{array}{c}3.77 \pm 0.17 \\
(46)\end{array}$ & $\begin{array}{c}3.94 \pm 0.17 \\
(37)\end{array}$ & $\begin{array}{c}3.78 \pm 0.14 \\
(76)\end{array}$ & $\begin{array}{c}3.84 \pm 0.04 \\
(5)\end{array}$ & $\begin{array}{c}3.81 \pm 0.17 \\
(16)\end{array}$ \\
\hline & Female & $\begin{array}{c}3.96 \pm 0.16 \\
(22)\end{array}$ & $\begin{array}{c}3.88 \pm 0.15 \\
(36)\end{array}$ & $\begin{array}{c}4.08 \pm 0.20 \\
(48)\end{array}$ & $\begin{array}{c}3.91 \pm 0.15 \\
(67)\end{array}$ & $\begin{array}{c}4.00 \pm 0.17 \\
(6)\end{array}$ & $\begin{array}{c}3.84 \pm 0.14 \\
(11)\end{array}$ \\
\hline \multirow[t]{2}{*}{ EP } & Male & $\begin{array}{c}2.93 \pm 0.15 \\
(23)\end{array}$ & $\begin{array}{c}2.81 \pm 0.12 \\
\quad(46)\end{array}$ & $\begin{array}{c}2.94 \pm 0.12 \\
(37)\end{array}$ & $\begin{array}{c}2.81 \pm 0.12 \\
(74)\end{array}$ & $\begin{array}{c}2.76 \pm 0.21 \\
(5)\end{array}$ & $\begin{array}{c}2.78 \pm 0.14 \\
(16)\end{array}$ \\
\hline & Female & $\begin{array}{c}3.05 \pm 0.13 \\
(21)\end{array}$ & $\begin{array}{c}2.90 \pm 0.14 \\
(36)\end{array}$ & $\begin{array}{c}3.09 \pm 0.17 \\
(48)\end{array}$ & $\begin{array}{c}2.93 \pm 0.13 \\
(66)\end{array}$ & $\begin{array}{c}3.03 \pm 0.09 \\
(6)\end{array}$ & $\begin{array}{c}2.90 \pm 0.27 \\
(11)\end{array}$ \\
\hline \multirow[t]{2}{*}{ PR } & Male & $\begin{array}{c}6.37 \pm 0.23 \\
(22)\end{array}$ & $\begin{array}{c}6.22 \pm 0.25 \\
(41)\end{array}$ & $\begin{array}{c}6.49 \pm 0.19 \\
(37)\end{array}$ & $\begin{array}{c}6.19 \pm 0.21 \\
(69)\end{array}$ & $\begin{array}{c}6.46 \pm 0.13 \\
(5)\end{array}$ & $\begin{array}{c}6.21 \pm 0.30 \\
(15)\end{array}$ \\
\hline & Female & $\begin{array}{c}6.73 \pm 0.24 \\
(21)\end{array}$ & $\begin{array}{c}6.39 \pm 0.20 \\
(33)\end{array}$ & $\begin{array}{c}6.70 \pm 0.21 \\
(46)\end{array}$ & $\begin{array}{c}6.44 \pm 0.24 \\
(67)\end{array}$ & $\begin{array}{c}6.78 \pm 0.11 \\
(5)\end{array}$ & $\begin{array}{c}6.34 \pm 0.19 \\
(12)\end{array}$ \\
\hline
\end{tabular}

In brackets, sample size.

Table 3. Values of ANOVA test $(F)$ and Kruskal-Wallis test $(H)$ and probability $(p)$ comparing paraproct length (PA), epiproct length (EP) and prementum length (PR) in periods P1 and P2 (see text) in male and female exuviae of Boyeria irene (Fonscolombe, 1838) sampled in three sections (Casas, Miranda, Sotoserrano) from the Francia River.

\begin{tabular}{|c|c|c|c|c|c|c|c|}
\hline & \multicolumn{3}{|c|}{ Casas } & \multicolumn{2}{|l|}{ Miranda } & \multicolumn{2}{|l|}{ Sotoserrano } \\
\hline & & Test & $\mathrm{p}$ & Test & $\mathrm{p}$ & Test & $\mathrm{p}$ \\
\hline \multirow[t]{3}{*}{ Males } & PA & $\mathrm{F}_{1,67}=6.240$ & 0.0149 & $\mathrm{~F}_{1,111}=25.64$ & $<0.0001$ & $\mathrm{H}=0.207$ & 0.6497 \\
\hline & EP & $H=8.166$ & 0.0043 & $\mathrm{~F}_{1,109}=27.84$ & $<0.0001$ & $\mathrm{H}=0.015$ & 0.9014 \\
\hline & PR & $\mathrm{F}_{1,61}=5.270$ & 0.0251 & $\mathrm{~F}_{1,104}=50.59$ & $<0.0001$ & $H=3.688$ & 0.0529 \\
\hline \multirow[t]{3}{*}{ Females } & PA & $F_{1,55}=3.650$ & 0.0614 & $\mathrm{H}^{\prime}=24.459$ & 0.0001 & $\mathrm{~F}_{1,18}=4.930$ & 0.0394 \\
\hline & $\mathrm{EP}$ & $\mathrm{F}_{1,54}=15.200$ & 0.0003 & $\mathrm{~F}_{1,116}=32.320$ & $<0.0001$ & $\mathrm{H}=5.333$ & 0.0209 \\
\hline & PR & $\mathrm{F}_{1,51}=28.440$ & $<0.0001$ & $F_{1,115}=36.310$ & $<0.0001$ & $F_{1,18}=24.110$ & $<0.0001$ \\
\hline
\end{tabular}

In bold, significant values.

Table 4. Values of ANOVA test $(\mathrm{F})$ and Kruskal-Wallis test $(\mathrm{H})$ and the probability $(\mathrm{p})$ comparing paraproct length (PA), epiproct length (EP) and prementum length (PR) in male and female exuviae of Boyeria irene (Fonscolombe, 1838) sampled in three sections (Casas, Miranda, Sotoserrano) from the Francia River during period 1 and 2 (see text).

\begin{tabular}{lllclc}
\hline & & Period 1 & & Period 2 & \\
& & Test & $\mathrm{p}$ & Test & $\mathrm{p}$ \\
\hline Males & $\mathrm{PA}$ & $\mathrm{H}=2.940$ & 0.2299 & $\mathrm{~F}_{2,135}=0.230$ & 0.7928 \\
& $\mathrm{EP}$ & $\mathrm{H}=4.867$ & 0.0877 & $\mathrm{~F}_{1,133}=0.470$ & 0.6286 \\
\multirow{4}{*}{ Females } & $\mathrm{PR}$ & $\mathrm{F}_{2,61}=2.200$ & 0.1195 & $\mathrm{~F}_{2,122}=0.340$ & 0.7146 \\
& $\mathrm{PA}$ & $\mathrm{F}_{2,73}=3.760$ & 0.0280 & $\mathrm{~F}_{2,117}=1.470$ & 0.2350 \\
& $\mathrm{EP}$ & $\mathrm{F}_{2,72}=0.720$ & 0.4896 & $\mathrm{H}=2.738$ & 0.2544 \\
& $\mathrm{PR}$ & $\mathrm{F}_{2,69}=0.320$ & 0.7239 & $\mathrm{~F}_{2,115}=1.610$ & 0.2047 \\
\hline
\end{tabular}

In bold, significant values.

System, in which a balanced sex ratio at emergence has been recorded (Casanueva et al. 2017).

Populations of $B$. irene located in warm areas of the southern Iberian Peninsula $\left(15^{\circ} \mathrm{C}\right.$ average annual temperature) show asynchronous emergence that lasts up to 150 days (Ferreras-Romero 1997). In the mountains of the Central System of Iberia, the emergence of $B$. irene was analysed by Casanueva et al. (2017) in the River Eresma (at $1200 \mathrm{~m}$ a.s.l., with a mean annual temperature of $10^{\circ} \mathrm{C}$, located $172 \mathrm{~km} \mathrm{E}$ 
of the Francia River), where emergence started almost ten weeks later than in the south, with no data on when it ended (2016). In this same mountain range, but in the Frío and Agadón rivers (at $745-830 \mathrm{~m}$ a.s.l., with $12.6^{\circ} \mathrm{C}$ mean annual temperature (Ninyerola et al. 2005), and $28-57 \mathrm{~km} \mathrm{~W}$ of the Francia River), the emergence started on 4 June and lasted until September (Velasco et al. 2018). In the present study, carried out at $400-595 \mathrm{~m}$ a.s.l. and with $14.0-15.1^{\circ} \mathrm{C}$ of mean annual temperature, the emergence period started at the end of June and was remarkably short (7-10 weeks depending on the points). However, in our case it is possible that some adults may have emerged later in the season, as in the case with other anisopterans (Corbet 1957) and were not detected. In odonates, emergence phenology can vary annually depending on water temperature (Farkas et al. 2012), and a linear relationship between air and stream water temperature has been shown (Erickson and Stefan 2000). This coincides with the behaviour of $B$. irene in central Iberia. Our data show that, in addition, even within the same river and for the same year, there may be a time lag in the duration of emergence: the adults begin to emerge earlier in the river mouth, probably because the temperature of the water is higher than in the other sections of the river at higher altitudes.

Our data are consistent with other studies in that females are larger than males (Nunes et al. 2021). In both sexes, the first adults to emerge are larger than those that emerge later. Several options can be proposed to explain this: a) Larvae can reach large size before emergence either by foraging more intensively, or by prolonging the larval stage (Falck and Johansson 2000). In large pond-dwelling Anisoptera, such as Anax imperator Leach, 1815, the adults that emerge later are larger than those that emerge earlier, perhaps because they have more time for larval development (Minot et al. 2019). In mountain rivers, larval development may have a winter diapause in F-0 instar larvae caused by low water temperature (case of Cordulegaster boltonii, Ferreras-Romero and Corbet 1999). However, in warmer southern Iberia, B. irene does not have this diapause (Ferreras-Romero 1997) and in central Iberia, which has a colder climate, only a few larvae spend winter as F-0 (Velasco et al., 2018). Therefore, this is a species with cohort splitting (Ferreras-Romero 1997; Velasco et al. 2018). Since body development is a function of the food obtained (Plaistow and SivaJothy 1999), adults that emerge early in our study area must have reached a large size (instar F-0), probably due to the availability to have sufficient food. b) In our study area, few exuviae were found at the mouth (Sotoserrano sampling site), suggesting that this site is less suitable for the species. The size of male exuviae at this site did not differ between periods, but that of females did, suggesting that large size of females is an important trait here. In odonates, the first adults to emerge have more time to reproduce than the later ones (Plaistow and Siva-Jothy 1999). Furthermore, in non-territorial species, large size confers advantages for females (Purse and Thompson 2003). Males of $B$. irene are not considered territorial, although they do patrol flights (Miller and Miller 1985). Minot et al. (2019) found in A. imperator, a territorial species, a positive correlation between the size of the exuvia and the size of the teneral adults, while Wonglersak et al. (2020) showed that in non-territorial anisopterans wing length does not vary between adults that emerged earlier and later. If the same is true for $B$. irene, then the larger size of females could provide advantages in terms of fecundity (Wickman and Karlsson 1989). 
On the other hand, some odonates present a positive correlation between latitude and body size (Hassall et al. 2014). Laboratory experiments carried out at constant temperature with odonates show that body size decreases with the reduction of the photoperiod (Johansson and Rowe 1999). So, within the species distribution range, those specimens that occupy northern latitudes would be smaller than those from southern ones. Our sampling was done in a geographically small zone, with no possibility of latitude influencing size. However, some environmental factors vary here, mainly the slope of the terrain, air temperature and probably water temperature. In mountain rivers, the slope of the terrain and the consequent water drift, mainly influence the presence-absence of larvae rather than their size (Naman, Rosenfeld, and Richardson 2016). In terms of temperature, the temperature-size rule suggests that the body size of adult specimens may be smaller in warmer areas (Atkinson et al. 2006). Our results show that the size of $B$. irene exuviae does not vary along the river, which suggests that the water temperature varies little between the three river segments studied.

\section{Acknowledgements}

An anonymous reviewer improved the first version of the manuscript. Ruth Breeze and Jennifer Smith improved the English.

\section{Disclosure statement}

No potential conflict of interest was reported by the authors.

\section{References}

Atkinson, D. (1994), 'Temperature and Organism Size - A Biological Law for Ectotherms?', Advances in Ecological Research, 25, 1-58.

Atkinson, D., Morley, S.A., and Hughes, R.N. (2006), 'From Cells to Colonies: At What Levels of Body Organization Does the 'Temperature-Size Rule' Apply?', Evolution \& Development, 8, 202-214.

Boudot, J.P., Kalkman, V.J., Azpilicueta Amorín, N.M., Bogdanovic, T., Cordero Rivera, A., Degabriele, G., Dommanget, J.L., Ferreira, S., Garrigos, B., Jovic, M., Kotarac, M., Lopau, W., Marinov, M., Mihokovic, N., Riservato, E., Samraoui, B., and Schneider, W. (2009), 'Atlas of the Odonata of the Mediterranean and North Africa', Libellula Supplement, 9, $1-256$

Casanueva, P., Hernández, M.A., Campos, F., and Santamaría, T. (2017), 'Boyeria Irene (Fonscolombe, 1838) y Cordulegaster Boltonii (Donovan, 1807) (Odonata): Dos Estrategias en Cuanto a Sustratos de Emergencia de Larvas en un Mismo Hábitat', Graellsia, 73, e059.

Casanueva, P., Santamaría, T., Hernández, M.A., Sánchez-Sastre, L.F., Teixeira, A., Bennas, N., El Haissoufi, M., Ferreras-Romero, M., and Campos, F. (2020), 'Biometric Differences in Iberian and Maghrebi Populations of Cordulegaster Boltonii (Odonata: Cordulegastridae)', European Journal of Entomology, 117, 260-264.

Charpentier, T. (1825), 'Horae Entomologicae, Adjectis Tabulis Novem Coloratis', Wratislavia: A. Gosohorsky.

Charpentier, T. (1840), Libellulinae Europaeae Descriptae ac Depictae, Leipzig: Leopold Voss.

Corbet, P.S. (1954), 'Seasonal Regulation in British Dragonflies', Nature, 174, 655-655. 
Corbet, P.S. (1957), 'The Life-History of the Emperor Dragonfly Anax Imperator Leach (Odonata: Aeshnidae)', The Journal of Animal Ecology, 26, 1-69.

Corbet, P.S. (1964), 'Temporal Patterns of Emergence in Aquatic Insects', The Canadian Entomologist, 96, 264-279.

Corbet, P.S. (2004), Dragonflies: Behaviour and Ecology of Odonata (rev. ed.), Colchester: Harley Books.

Cordero-Rivera, A., and Stoks, R. (2008), 'Mark-Recapture Studies and Demography', in Dragonflies and Damselflies. Model Organisms for Ecological and Evolutionary Research, ed.

A. Córdoba-Aguilar, Oxford: Oxford University Press, pp. 7-20.

Donovan, E. (1807), The Natural History of British Insects (Vol. 12), London: Author, p. 430.

Erickson, T.R., and Stefan, H.G. (2000), 'Linear Air/Water Temperature Correlations for Streams during Open Water Periods', Journal of Hydrologic Engineering, 5, 317-321.

Falck, J., and Johansson, F. (2000), 'Patterns in Size, Sex Ratio and Time at Emergence in a South Swedish Population of Sympetrum Sanguineum (Odonata)', Aquatic Insects, 22, 311-317.

Farkas, A., Jakab, T., Tóth, A., Kalmár, A.F., and Dévai, G. (2012), 'Emergence Patterns of Riverine Dragonflies (Odonata: Gomphidae) in Hungary: Variations between Habitats and Years', Aquatic Insects, 34, 77-89.

Ferreras-Romero, M. (1997), 'The Life Cycle of Boyeria Irene (Fonscolombe, 1838) (Odonata: Aeshnidae) in the Sierra Morena Mountains (Southern Spain)', Hydrobiologia, 345, 109-116.

Ferreras-Romero, M, and Suhling, F. (2021), 'On the Dimorphism Shown by the Females of Boyeria irene (Odonata: Aeshnidae) in a Southern Spain Population', Libellula Supplement, $16,115-125$.

Fonscolombe, B. (1838), 'Monographie Des Libellulines Des Environs D'Aix', Annales de la Société Entomologique de France, 7, 75-106.

Hassall, C., Keat, S., Thompson, D.J., and Watts, P.C. (2014), ' Bergmann's rule is maintained during a rapid range expansion in a damselflyDamselfly', Global Change Biology, 20, 475-482.

Hassall, C., and Thompson, D.J. (2008), 'The Effects of Environmental Warming on Odonata: A Review', International Journal of Odonatology, 11, 131-153.

Horne, C.R., Hirst, A.G., and Atkinson, D. (2015), 'Temperature-Size Responses Match Latitudinal-Size Clines in Arthropods, Revealing Critical Differences between Aquatic and Terrestrial Species', Ecology Letters, 18, 327-335.

Johansson, F., and Rowe, L. (1999), 'Life History and Behavioral Responses to Time Constraints in a Damselfly', Ecology, 80, 1242-1252.2.0.CO;2]

Köppen, W., and Geiger, R. (1936), 'Das geographische System der Klimate', Berlin: Gebrüder Borntraeger Verlagsbuchhandlung.

Leach, W.E. (1815), 'Entomology', in Edinburgh Encyclopaedia (Vol. 9), ed. D. Brewster, Edinburgh: William Blackwood and John Waugh, pp. 57-172.

Linnaeus, C. (1758), Systema Naturae (10th ed.), Holmiae: Laurentius Salvius.

Miller, A.K., and Miller, P.L. (1985), 'Simultaneous Occurrence of Crepuscular Feeding and Sexual Activity in Boyeria irene (Fonsc.) in Southern France (Odonata, Aeshnidae)', Entomologist's Monthly Magazine, 121, 123-124.

Minot, M., Le Gall, M., and Huste, A. (2019), 'Biometry of the Large Dragonfly Anax imperator (Odonata: Aeshnidae): a Study of Traits from Larval Development to Adults', European Journal of Entomology, 116, 269-280.

Müller, O.F. (1764), Fauna Insectorum Fridrichsdalina, Hafnia et Lipsia: F. Gleditsch, pp. 1-96.

Naman, S.M., Rosenfeld, J.S., and Richardson, J.S. (2016), 'Causes and Consequences of Invertebrate Drift in Running Waters: From Individuals to Populations and Trophic Fluxes', Canadian Journal of Fisheries and Aquatic Sciences, 73, 1292-1305.

Ninyerola, M., Pons, X., and Roure, J.M. (2005), Atlas Climático Digital de la Península Ibérica. Metodología y Aplicaciones en Bioclimatología y Geobotánica, Bellaterra: Universidad Autónoma Barcelona. 
Nunes, L., Casanueva, P., Santamaría, T., Hernández, M.A., and Campos, F. (2021), 'Useful Biometric Variables in Iberian Exuviae of Boyeria Irene (Fonscolombe, 1838) (Odonata: Aeshnidae)', International Journal of Odonatology, 24, 158-168.

Plaistow, S., and Siva-Jothy, M.T. (1999), 'The Ontogenetic Switch between Odonate Life History Stages: Effects on Fitness When Time and Food Are Limited', Animal Behaviour, 58, 659-667.

Purse, B.V., and Thompson, D.J. (2003), 'Emergence of the Damselflies, Coenagrion Mercuriale and Ceriagrion Tenellum (Odonata: Coenagrionidae), at Their Northern Range Margins, in Britain', European Journal of Entomology, 100, 93-99.

Santamaría, T., Casanueva, P., Nunes, L., and Campos, F. (2019), 'Libélulas del Sistema Central. Colores en vuelo, Ávila: Universidad Católica de Ávila.

Sulzer, J.H. (1776), 'Die Wasserjungfer', in Dr Sulzers Abgekürzte Geschichte der Insecten nach dem Linnaeischen System: Erster Theil, Winterthur: H. Steiner, pp. 166-169.

Velasco, T., Norling, U., Campos, F., and Ferreras-Romero, M. (2018), 'The Life Cycles of Boyeria Irene and Onychogomphus Uncatus (Odonata: Aeshnidae, Gomphidae) in Western Spain: A Biometric Study', European Journal of Entomology, 115, 684-696.

Wenger, O.-P. (1959), 'Die Beiden of Formen Von Boyeria Irene (Odonata-Aeschnidae)', Mitteilungen der Schweizerischen Entomologischen Gesellschaft, 23, 304-311.

Wickman, P.O., and Karlsson, B. (1989), 'Abdomen Size, Body Size and the Reproductive Effort of Insects', Oikos, 56, 209-214.

Wonglersak, R., Fenberg, P.B., Langdon, P.G., Brooks, S.J., and Price, B.W. (2020), 'Temperature-Body Size Responses in Insects: A Case Study of British Odonata', Ecological Entomology, 45, 795-805.

Zeuss, D., Brunzel, S., and Brandl, R. (2017), 'Environmental Drivers of Voltinism and Body Size in Insect Assemblages across Europe', Global Ecology and Biogeography, 26, 154-165. 